\title{
LEARNER PERSPECTIVE ON ENGLISH PRONUNCIATION TEACHING IN AN EFL CONTEXT
}

\author{
ELINA TERGUJEFF \\ University of Jyväskylä \\ elina.tergujeff@jyu.fi
}

\begin{abstract}
This paper reports on an interview study with EFL learners that aimed to explore learners' perceptions and views on English pronunciation teaching. The participants of the present study were ten EFL learners studying in the public educational system of Finland. Six of the participants were pupils attending basic education class nine, i.e. 15- to 16-year-old lower secondary level pupils. Two were primary level pupils attending basic education class four (aged 10), and two were upper secondary school pupils (aged 18). The interviews were thematic, and the learners were encouraged to speak freely about the English pronunciation teaching they were receiving and their opinions on this. In addition, they were asked to discuss their goals in English pronunciation, and to consider their pronunciation learning in class and out of class. The interviews were part of a wider study, mapping English pronunciation teaching practices in the context of Finnish schools.

On the basis of the findings, the learners do not seem to have aspirations to native-like pronunciation, but rather aim at achieving intelligible and fluent speech. Only few reported an accent preference (British or American). The primary level learners expressed satisfaction with the amount of pronunciation teaching, whereas most of the lower and upper secondary level learners claimed that pronunciation teaching was insufficient. Despite their criticisms of their pronunciation teaching, the learners reported that they had learnt English pronunciation at school. In addition, many of the learners described learning pronunciation outside school, e.g. through media and personal encounters.
\end{abstract}

Keywords: English as a foreign language, EFL, pronunciation teaching, interview.

\section{Introduction}

In Finland, English is taught in schools as a foreign language. It is the most popular language study option and, according to statistics, almost all schoolchildren study English as their first foreign language, beginning their study of English already at the primary level (Kumpulainen 2010, 88-89; for more information about the Finnish educational system, see ibid., 222). Although English has no official status in Finland, globalisation and the media have brought English into the everyday lives of Finns, also outside of the field of education: English is heard and seen in the linguistic landscape, needed in working life, and used in leisure activities, especially by youth. Moreover, Finns generally have a positive attitude to English, and they do not consider it a threat to their native languages or culture. (Leppänen et al. 2011.) The present study uses Finnish 
schools as an example of an EFL context of English pronunciation teaching, and is motivated by the claims made about the possible neglect of teaching in this area, both in Finland (Lintunen 2004, 215; Iivonen 2005, 46) and internationally (e.g. Fraser 2000, Gilbert 2010). Also, it adds a learner perspective to the series of studies in English pronunciation teaching in Finland conducted by the author (Tergujeff 2010, 2012a, 2012b).

This article is part of a larger study on English pronunciation teaching in the context of Finnish schools, focussing here on the perspective of learners on the topic. More specifically, the paper reports on an interview study with EFL learners that aimed to explore learners' perceptions and views on English pronunciation teaching in the Finnish school context from primary to upper secondary level. The study sought to answer the following research questions:

1. What do Finnish learners indicate as their goals in English pronunciation?

2. In the learners' view, how is English pronunciation taught in Finnish schools?

3. How do Finnish learners evaluate the English pronunciation teaching they are receiving, and their learning of English pronunciation?

The study addresses several issues related to pronunciation teaching and learning: learners' goals, teaching practices, and learners' evaluations of their teaching. With respect to teaching practices, the teaching of phonemic script has special focus in this study. It has been suggested that phonemic transcription is a beneficial learning tool for Finnish learners of English (see Lintunen 2004). Because the present study addresses such a wide variety of issues, a separate literature review is not given here, but relevant previous research is discussed in section three in connection with the analysis.

\section{The present study}

The participants of the present study were ten EFL learners, studying English in the public educational system in Finland. Six of the participants were pupils attending basic education class nine, i.e. 15- to 16-year-old lower secondary level pupils. Two were primary level pupils attending basic education class four (aged 10), and two were upper secondary school pupils (aged 18). Participant information is presented in Table 1. The pupils came from three different schools, and one of the pupils (marked with *) studied English with a special education teacher separately from the rest of his class. The names have been changed to ensure participant anonymity. All of the participants volunteered to take part in the study, and signed a written consent allowing the interviews to be used for research purposes. In the case of the under-aged participants, the consent forms were signed by their guardians.

\begin{tabular}{ccc}
\hline participant & level & school \\
\hline Maria & primary & $\mathrm{A}$ \\
\hline Hanna & primary & $\mathrm{A}$ \\
\hline Anna & lower secondary & $\mathrm{B}$ \\
\hline Liisa & lower secondary & $\mathrm{B}$ \\
\hline
\end{tabular}




\begin{tabular}{clc}
\hline participant & \multicolumn{1}{c}{ level } & school \\
\hline Emma & lower secondary & $\mathrm{B}$ \\
\hline Selma & lower secondary & $\mathrm{B}$ \\
\hline Valtteri & lower secondary & $\mathrm{B}$ \\
\hline Lassi & lower secondary & $\mathrm{B}$ \\
\hline Suvi & upper secondary & $\mathrm{C}$ \\
\hline Linda & upper secondary & $\mathrm{C}$ \\
\hline
\end{tabular}

Table 1. Participant information.

To answer the research questions set for the present study, thematic interviews were conducted with the participants. In the interviews, the learners were encouraged to speak freely about the English pronunciation teaching they were receiving and their opinions on this. In addition, they were asked to discuss their goals in English pronunciation, and to evaluate their pronunciation learning in class and out of class. As stimuli for the discussion, the interviewees' own EFL textbooks and a list of words in phonemic script were used. The interviews were framed such that the researcher told the interviewees that she did not know how English pronunciation was taught in Finnish schools and considered the pupils as the experts best able to provide her with this information (Fontana \& Prokos 2007, 70). The interviews were conducted in the learners' native tongue, i.e. in Finnish. In this article, I refer to the original Finnish-language data, but translations into English are also provided. The interviews took place in various surroundings: at the learners' school, on the premises of the researcher's institution, and also at the home of one of the interviewees (the youngest participants were interviewed in the home of one of them to reduce possible nervousness on the part of the children). In the school context, appropriate permissions were asked from and granted by the head of school and the municipal education authorities.

The interviews were audio-recorded and transcribed by the author for qualitative content analysis (Kvale 2007, 105). The content analysis was applied to the data to identify the central thematic categories. Six categories emerged: (1) pronunciation goals, (2) pronunciation exercises in textbooks, (3) pronunciation teaching practices, (4) pronunciation models, (5) amount of pronunciation teaching, and (6) pronunciation learning. Conclusions were drawn for each of the six categories based on interpretations of the interview excerpts. To avoid researcher bias, researcher triangulation (Denzin 1978) was carried out: two established researchers gave their analysis of the data in addition to the author's. The purpose of triangulation was also to gain a deeper understanding of the topic by discussing the data in a group.

\section{Analysis and discussion}

The results of the qualitative analysis of this interview study are described below. The analysis is discussed in connection with the results. The quotes illustrate recurrent or otherwise interesting themes spotted in the analysis. 


\subsection{Learners' pronunciation goals}

A review of the previous research on learners' goals in English pronunciation, accent preferences and attitudes towards accents reveal a number of interesting results. Many learners seem to have negative attitudes towards (their own) non-native and outer circle (Kachru 1985) varieties (e.g. Pihko 1997, Dalton-Puffer et al. 1997), and they often prefer an accent that is familiar to them: in Europe, this seems to be British Received Pronunciation (e.g. Dalton-Puffer et al. 1997, Genoz \& Garcia Lecumberri 1999, Waniek-Klimczak \& Klimczak 2005). Learners' aspirations to learn a native-like pronunciation have been recorded in both ESL (Derwing 2003) and EFL (e.g. Janicka et al. 2005) environments. However, in a survey of Polish EFL learners by WaniekKlimczak (1997), only a minority wished to sound native-like.

In the present study, the majority of the learners reported fluency and intelligibility as their main goals in English pronunciation. In addition, they did not have ambitions to the production of a specific variety, as pointed out by the following learner:

(1) "[Haluaisin oppia] hyvää englantia, ymmärrettävää englantia. Se menee monesti semmoseksi suomen englanniksi, semmoseksi töksähteleväksi, mutta haluaisin osata semmoista sujuvaa ja ei sillä oo väliä onkse brittiä vai amerikkalaista mutta kunhan se olis oikeen sellasta ymmärrettävää ja sujuvaa."

([I would like to learn] good English, intelligible English. I often slip into a kind of Finnish English, awkward-sounding, but I would like to be fluent. It doesn't matter whether it's British or American, as long as it's genuinely intelligible and fluent.)

(Anna, lower secondary level)

For the learners interviewed for the present study, native-like pronunciation does not seem to be a goal. Some of the learners pointed out that it does not bother them if people hear that they have a foreign accent, while one learner clearly stated his wish to be identified as a Finn (cf. Jones 2001 on accent as a reflection of identity), when asked whether he would find it desirable to speak without a foreign accent:

(2) "Ei se hienoa olis. Haluan korostaa sitä että en ole brittiläinen vaan olen suomalainen."

("No, it wouldn't be nice. I want to emphasise that I'm not British but a Finn.")

(Valtteri, lower secondary level)

If native-like pronunciation was mentioned by the learners, they referred to it as if it were only wishful thinking. A couple of learners considered it "nice" if they could speak like a native speaker, but this was still not their main goal. They emphasised intelligibility and fluency, and also stated that it did not matter if listeners notice their foreign accent. The results perhaps reflect the general change in attitudes towards nonnative accents and accented speech: it is widely accepted to speak English with a foreign accent as long as it does not compromise intelligibility (cf. the work of Jenkins, e.g. Jenkins 2000). It has also been suggested that in English pronunciation teaching in Europe, the use of "a type of International English" as pronunciation model is gaining a foothold (Henderson et al. 2012, Tergujeff 2012b). 


\subsection{Pronunciation exercises in textbooks}

Textbooks play an important role in foreign language teaching. In the Finnish context, the dominance of textbooks over other teaching materials has been shown in a survey by Luukka et al. (2008), and, with particular reference to English pronunciation teaching, by Tergujeff (2012b). In the present study, the learners' textbooks were used as stimuli for discussion in the interviews by asking them to introduce typical pronunciation exercises in their textbooks. This was not an easy task because it seemed that pronunciation is not a frequent textbook topic. Many had to struggle to find pronunciation exercises:

(3) ’Emmä tiiä onks täälä semmosia. -- Ehkä enemmän just niissä yläasteen ku lukion. Miten mä en löydä täältä niinku yhtään mitään?"

("I don't know if there are any. -- Maybe there were more in the lower secondary level books. How come I don't find anything?")

(Suvi, upper secondary level)

Research-based information on the relative proportion of pronunciation exercises in Finnish EFL textbooks is not available. A classification of pronunciation teaching materials in Finnish EFL textbooks, however, is available in a recent textbook analysis (Tergujeff 2010). This textbook analysis revealed a range of pronunciation teaching materials: phonetic training, reading aloud, imitation, rhymes, rules and instructions, awareness-raising activities, spelling, dictation, and ear training. In the learners' view, the range of pronunciation teaching materials in their EFL textbooks seems to be narrower than was indicated by the textbook analysis. The learners mentioned word stress exercises, in which the learners listen to words and mark the correct stress placement, as a frequent exercise type in the lower secondary school textbooks that they used. Another frequently mentioned exercise type was a list of words and expressions (presented in a text box) preceding a text. In these lists, words and expressions from the text are highlighted before the text is studied. The lists can be listened to on the CD accompanying the teacher's book; according to the learners a typical classroom procedure is repeating words and expressions aloud together as pronunciation practice.

(4) "No tuossa on siitä mihin se painotus tulee. Ja tuossahan on noita merkkejä että miten se äännetään. -- Ja sit se on tässä tekstikirjassa ku on ennen tekstejä näitä laatikoita niin nämä me käydään aina läpi”.

("Here's one on where the stress falls. And here are symbols showing how it's pronounced. -- And in the textbook there are boxes like this before each text, and we always study them.")

(Liisa, lower secondary level)

The primary level pupils mentioned that their textbook includes a CD. The pupil's CD is a concise version of the teacher's $\mathrm{CD}$, and usually features the audio version of the key texts of the textbook. Maria stated that the CD was specifically for pronunciation practice at home:

(5) “Kuuntelen sitä ja siinä on semmosia pieniä taukoja et sen aikana voi ääntää niitä.”

("I listen to it, and there are pauses during which you can pronounce the words. ")

(Maria, primary level) 
Based on Luukka et al. (2008) and Tergujeff (2012b), textbooks are the most widely used teaching materials in foreign language teaching in Finland: almost all teachers use textbooks. Another proof of the major role of textbooks in foreign language teaching is offered here, as many of the learners stated that during the lessons they do not often skip things in the textbook but cover all of it during the term.

(6) "Kyllä me ollaan noita tehty. Että melkein kaikki asiat täältä kirjasta on käyty. Ettei kauheasti hypitä kyllä."

("Yes, we have done those. We have covered pretty much all of the book. We seldom skip stuff.")

(Selma, lower secondary level)

\subsection{Pronunciation teaching practices}

When the learners talked about the pronunciation teaching they were receiving at school, they mentioned very traditional teaching techniques: mostly imitation and reading aloud. This suggests that despite the recommendations in the literature on the subject (e.g. Morley 1991; Celce-Murcia et al. 2010, 44-45), pronunciation teaching relies heavily on mechanical production without moving on to controlled practice and, finally, communicative tasks, as recommended at the stage when the learner has already learnt to produce the segments of the target language. However, it may also be that the teaching practices include more general oral skills (conversational) tasks which the learners do not label as pronunciation activities, since in their minds these consist of segmental-level mechanical production. The typical classroom practices reported are well exemplified in the following excerpt from the interview with Valtteri (lower secondary level):

(7) Valtteri: Se perinteinen on se että opettaja sanoo sanan oikein ja oppilaat sanoo perässä. Yrittää ääntää samalla tavalla. No mitenkähän sitä nyt yleensäkään... opetellaan. Aika lailla sillä tavalla.

("The traditional way is that the teacher says the word correctly and the pupils repeat it. Try to pronounce it the same way. Let me think how do we usually... study. Well, pretty much like that.")

Interviewer: Tuleeko muita harjoituksia mieleen?

("Can you think of any other tasks?")

Valtteri: No niitä sellaisia kai että pitää kuunnella nauhalta niitä sanoja ja pitää siinä

kohtaa merkata missä se on se paino siinä sanassa.

("Well I guess those in which you have to listen to words and mark where the stress falls in that word.")

Interviewer: Mitä muuta opetetaan kuin painoa?

("What else do they teach, in addition to stress?")

Valtteri: Ei niitä enää sillä lailla opeteta kun nehän on tullu jo ala-asteella ne hommat että miten mitkä kirjaimet ääntyy missäkin tilanteessa minäkin ja tämmöset. Tämmöset hankalat sanat käydään erikseen. Aika lailla keskitytään niihin yksittäisiin äänteisiin että koko sana menee oikein.

("They don't teach that much anymore because it's all covered in primary school. The stuff about how letters are pronounced in different positions and that stuff. Difficult words are dealt with separately. We pretty much focus on individual sounds to get the whole word right.") 
It also seems common for teachers to deal spontaneously with pronunciation when difficulties appear; e.g. when a pupil is unable to pronounce something, or there is a recurrent mispronunciation. This aspect has been discussed by Burgess \& Spencer (2000), and by Macdonald (2002), who interviewed Australian ESL teachers reluctant to teach pronunciation. Macdonald mentions that pronunciation teaching is not always systematic but incidental in nature and that pronunciation is dealt with in class "as it comes up".

The present study focused in particular on the use of phonemic script in pronunciation teaching. This derives from the fact that the orthography of the learners' L1, Finnish, follows a principle of close letter-to-sound correspondence (Suomi et al. 2008,141 ), and thus phonemic transcription can be seen as a beneficial learning tool for them, helping them to tackle their difficulties with the sometimes ambiguous spelling of English (cf. Wells 1996). What is more, it has been suggested that transcription skills and English pronunciation skills correlate in advanced Finnish learners of English (Lintunen 2004). Based on the interviews in the present study, phonemic script is not very commonly used in pronunciation teaching. A similar de-emphasis was found in an earlier study, based on classroom observations of the teaching of Finnish EFL teachers (Tergujeff 2012a), and a retrospective learner survey in Lintunen (2004, 183-188). However, the participants of the present study often stated that even though their teaching did not at the moment make use of phonetic symbols, these had been used earlier in their education - typically already in primary school. This is also supported by the fact that the primary level pupils interviewed here reported receiving teaching of phonetic symbols. The following excerpt is from an interview with Emma who is currently in lower secondary school.

(8) Interviewer: Ne on tuttuja sulle?

("You are familiar with them?")

Emma: Joo mutta mä en oikein osaa niitä. Tai siis silleen en oo koskaan osannu näitä kovin hyvin.

("Yes but I don't really know them. I mean I have never known them that well.")

Interviewer: Niitä ei ole varmaan paljon sitten opetettukaan?

("So have they not been taught thoroughly?")

Emma: No ku ala-asteella mä en ollu todellakaan tosi hyvä niinku englannissa -- niin mä en oikein keskittyny enkä halunnukaan oikeen oppia sitä nii vasta motivaatio nousi ku halus lähtee ulkomaille, nii en mä muista näistä kauheesti.

("Well I wasn't very good at English in primary school -- so I didn't concentrate and didn't even want to learn English. I had no motivation until I wanted to go abroad, so I don't remember much about them.")

Interviewer: Eli niitä on opeteltu ala-asteella mutta nytkö ei enää?

("So the symbols were taught in primary school but not anymore?")

Emma: ei yläasteella ole minun mielestä paljoo opetettu näitä.

("No they haven't been taught much in lower secondary school in my opinion. ")

It seems likely that the interviewees had been taught phonetic symbols at some stage, even if they were not used in their current teaching, as despite the learners' tendency to downplay their skills, most of them were able to read phonemic transcriptions of single words presented to them in the interview. The idea was not to test their skills but to use 
transcription reading as a stimulus for the discussion. The transcriptions included words such as cat, fish, robot, anyone, religion, nothing and allergic.

The learners were divided on the usefulness of knowing phonemic script. This division was not linked to age or level of proficiency, and may perhaps have more to do with personal preference or learner type. The same division was found among respondents to a teacher survey (Tergujeff 2012b). Even the reasoning behind the opinions was similar in teachers and learners: those who saw it as beneficial referred to checking the correct pronunciation of words, and those who did not referred to the actual spelling of words, feeling that phonemic script would interfere with the learners' spelling, as in the following quote:

(9) “-- en mä oikeen ymmärtäny että miksi noita pitäs tolleen kattoa. Ku ei niitä oikeastikaan noin kirjoteta."

("I didn't understand why they should be seen like that. After all that's not how you write English anyway.")

(Emma, lower secondary level)

\subsection{Pronunciation models}

As stated in 3.1, the learners do not seem to have great ambitions towards achieving a native-like pronunciation, and no strong preferences for a specific accent. A recent survey suggests that the pronunciation models most commonly used English pronunciation teaching across Europe are British Received Pronunciation (RP) and General American (GA) (Henderson et al. 2012). This finding is supported by the view of the learners interviewed for the present study. According to learners, the varieties used in the teaching they receive are British and American. Most of the learners stated that both are used, and that one is typically the main variety whereas the other is introduced on the side.

(10) "Britti. Sitä on. Ollaan me käyty vähän tota amerikanenglantiakin ja niitä eroavaisuuksia katottu."

("It's British, that's what it is. We have also explored American English a little, looked at the differences.")

(Selma, lower secondary level)

The majority of the learners reported that the British variety was the main pronunciation model taught, while for some learners it was American English. Other varieties, or introductions to these, were seldom mentioned. Valtteri, however, mentioned Canadian English:

(11) "Kyllä se nyt ollu vähän kumpaakin [britti- ja amerikanenglantia] nytte niinku viimesinä vuosina. Että sehän on alkanu ala-asteelta ja seiskaluokalle saakka brittienglantina mutta sitten meillä on ollut justiinsa tämä kirja missä se korosti niitä eroja ja täällon paljo tehtäviä alussa niistä. Täällon näitä sanaeroja ja kaikkee ja ääntämiseroja. Sitten täällä on kanadanenglantiakin. Tai täällä on pari kappaletta missä on vaan tehtäviä näistä." 
("It's been both [British and American] these past few years. It began as British English in primary school until seventh grade but now we've had this book that emphasises the differences and there are lots of exercises on them. Differences in words and everything, and pronunciation. And there's Canadian English even. I mean there are a couple of texts with exercises.")

(Valtteri, lower secondary level)

The use of this variety has already come up in a previous study: in a recent survey (Tergujeff 2012b), 21.1\% of the respondents (EFL teachers working in Finland, $n=76$ ) reported that they use Canadian English for receptive pronunciation tasks. It was suggested that this is due to the current EFL textbooks used in Finland, which also include audio material in Canadian English (ibid.). The use of different varieties offers opportunities for raising accent awareness, and even for receptive accent addition (i.e. adding accents to one's receptive repertoire by means of perceptual training, as suggested by Jenkins 2000, 208-212). As there is great variation in the pronunciation of English worldwide, it is good for learners to be aware of this and prepared to encounter people who speak differently from the main pronunciation model offered to them in teaching; see e.g. Cunningham (2009).

\subsection{Amount and success of pronunciation teaching}

In recent years, it has repeatedly been claimed that pronunciation teaching is generally neglected, both in Finland (Iivonen 2005, 46; Lintunen 2004, 215) and internationally (e.g. Fraser 2000, Gilbert 2010). This claim can be seen as related to the rise of Communicative Language Teaching (CLT), which started at the end of the 1970s. The proponents of CLT largely rejected traditional pronunciation teaching as incompatible with teaching language as communication (Celce-Murcia et al. 2010, 11), yet offered no comprehensible communicative set of methods in return (ibid., 9). Also, many teachers find pronunciation difficult to teach (Macdonald 2002), and are of the opinion that their training in how to teach pronunciation has been insufficient (Breitkreutz et al. 2001; Foote et al. 2011; Henderson et al. 2012; Tergujeff 2012b).

In the present study, learners were asked how much attention was paid to pronunciation in the teaching they were receiving, and what they thought of the amount they received. The primary level pupils reported receiving plenty of pronunciation teaching. Added to the findings on the teaching of phonemic script, it seems that more attention is paid to pronunciation teaching at the primary level than at the lower and upper secondary levels. This is in line with the national core curriculum for basic education (Finnish National Board of Education 2004), which emphasises the primacy of oral language skills in teaching foreign languages, and states that the weight given to written skills is to be added gradually (ibid., 139). The present study gives grounds to speculate that currently the weight given to written skills is added at the cost of pronunciation, as the majority of the learners expressed dissatisfaction with the amount of pronunciation teaching at the lower and upper secondary levels. They stated that this component had not been dealt with sufficiently, and they hoped for more teaching in this area. This view is exemplified by the following quote: 
(12) “Aika vähän minun mielestä. Siis siihen keskitytään ihan liian vähän koska se olis paljon tärkeämpää kun mitä sitä nyt harjotellaan. Minusta se on aika vähästä mitä me sitä harjotellaan. Ja just että koko sen tunnin pitäs pystyä puhumaan englanniksi jotenkuten ettei aina menis siihen että puhuu sitte oikeesti suomeksi ja sanoo jotain vähän sinne päin. Tulis semmosta sujuvuutta."

("There's way too little focus on that, as pronunciation is much more important than you'd figure from the amount of practice at school. I think we practise pronunciation very little. And I think we should speak English the whole lesson and not slip into Finnish. It would bring that fluency.")

(Anna, lower secondary level)

While many of the learners expressed that pronunciation teaching is insufficient, some appeared to have taken action on their own initiative to develop their pronunciation skills. They had adopted an active role in the learning process, both in class and out of class. Emma, for example, said she reads texts aloud at home to practise pronunciation, and that she regularly asks her teacher how words are pronounced, as exemplified in the following quote. It also appears that she has identified a way of learning that suits her, and that she is aware of her own learning.

(13) "Olen ihan hyvin kyllä oppinu. Siis minä ite aina tykkään kysyä että miten tämä äännetään kun en tiiä. Ja silleen oon ihan hyvin oppinu."

("I have learnt pretty well. I like to ask how something is pronounced if I don't know it.

I've learnt well that way.")

(Emma, lower secondary level)

Despite the fact that most learners interviewed for the present study claimed that pronunciation teaching was insufficient, they nevertheless considered that they had learnt English pronunciation at school. "Learning by doing" - presumably meaning exposure to English and practising it by speaking - was mentioned frequently by the learners. The learners seemed to be saying that it would be impossible not to learn pronunciation at school, which gives an interesting addition to the discussion on whether pronunciation is a teachable skill in the first place. The positive effects of formal pronunciation instruction have been challenged by Suter (1976) and Purcell \& Suter (1980), but most studies conducted in this area have reported on developed pronunciation skills after teaching experiments (for a synthesis see Saito 2012). The following quote from Anna is an example of how obvious the learning of English pronunciation in class is to the interviewees.

(14) “Joo, kyllähän sitä väkisinkin oppii ja kun kuuntelee niin, tekemällä oppii."

("Oh yes, you just learn, and when you listen, yes, you learn by doing.")

(Anna, lower secondary level)

The learners reported they had also learnt English pronunciation outside school. It seems that the majority of them engage in various leisure activities that include the use of English. When asked whether he had learnt English pronunciation at school, Valtteri was of the opinion that leisure activities had taught him more about English pronunciation than formal teaching: 
(15) “No, jaa-a. Enpä nyt sanois. Ehkä tietenki jonkun verran. Sehän on että ääntämään oppii aina ku puhuu. Koulussa tulee aika paljon kuitenkin käytettyä englantia kun nää on englannin tunteja. Kyllä sitä on jonkun verran tullu opittua mutta suurin osa tulee vapaaajalta."

("Well, I wouldn't say so. Perhaps a little. You learn to pronounce whenever you speak, that's how it is. At school we use quite a lot of English, as these are English lessons. I've learnt some but mostly in my free time.")

(Valtteri, lower secondary level)

The learners' descriptions of their pronunciation learning outside of the classroom included various contexts. However, many of them had to do with media. The learners seemed to feel that listening to music, watching television and films, and playing online games is beneficial to their learning of English pronunciation. Playing online games includes talking to other players using English as a lingua franca.

(16) “Aika paljo sillä lailla ku jotaki pelejä pelaa. Onlainina. Nii siinä käytetään aika paljon Skypea ja TeamSpeakiä ja näitä, että että voi kommunikoida. Se on helpompaa ku ruveta kirjottelemaan siinä kesken kaiken. Siinä oppii aika paljo.”

("Quite a lot by playing games online. We use Skype and TeamSpeak and so on, to communicate. It's easier than typing in the middle of the game. You learn a lot like that.") (Valtteri, lower secondary level)

Foreign contacts in person were also mentioned by the learners as learning situations. According to the interviewees, these encounters typically take place with tourists and foreign seasonal workers in Finland (as in the case of Lassi, lower secondary level).

(17) Lassi: Ääntämään? No en. Onhan se mitä kesällä ulkomaalaisten kans. Siinäki jotaki. ("To pronounce? No. Or well, a little with the foreigners in summertime. I guess that's something.")

Interviewer: Niin sä kuitenkin puhut joittenkin kanssa englantia koulun ulkopuolella?

Keitä ne ovat?

("So you do speak English with people outside school? Who are they?")

Lassi: No yleensä thaimaalaisten kanssa. Ja joskus kun pelaa netissä ni niitten ulkomaalaisten kanssa.

("Usually Thais. And sometimes when I play online I speak with the foreigners there.")

Overall, the learners seemed able to identify their own learning of English pronunciation in both formal and informal contexts. The English language is strongly present in Finnish society, and it is known from a nation-wide survey that young people in particular use English also in their leisure activities (see Leppänen et al. 2011). The present study sheds light on the language learning involved in these activities, as many of the interviewees were of the opinion that they have learnt English pronunciation while playing online games, listening to music, watching television and films, and encountering foreigners. 


\section{Conclusions}

The aim of the present paper was to explore learners' views on English pronunciation teaching in the context of Finnish schools from primary to upper secondary level. This interview study yielded the following main results in answer to the research questions. The learners considered intelligible and fluent speech to be their main goal in English pronunciation. They did not express aspirations for a native-like accent, and did not commonly have an accent preference. According to the learners, English pronunciation teaching mainly relies on traditional methods such as imitation and reading aloud. Tasks on word stress placement were also frequently mentioned. Phonemic script (on the usefulness of which the learners were divided) is used more in the teaching at the primary than lower or upper secondary level. The results also suggest that pronunciation teaching is not necessarily very systematic but rather is spontaneous in nature. Textbooks seem to play an important role in English pronunciation teaching. A British or American standard variety is generally used as the pronunciation model. Pronunciation is taught extensively at the primary level, and the learners expressed satisfaction with this. The learners at the lower and upper secondary level expressed the opinion that pronunciation is not paid enough attention to in teaching, and would like more pronunciation teaching. Notwithstanding, all the interviewees stated that their pronunciation skills had developed because of classroom activities. In addition, many reported learning pronunciation outside of the classroom, e.g. through media and personal encounters.

The results of the present study imply that more attention could be paid to pronunciation at the lower and upper secondary levels. According to the learners, it is not sufficient to focus on pronunciation at the primary level only; instead, they would like to see a continuation of pronunciation teaching at the later stages. The major role of textbooks in teaching imposes pressure on them, as there is a risk of language items being left out of the teaching if they are not dealt with in the textbook. In this connection, it is worth keeping the old proverb about "good servants but poor masters" in mind: textbooks are valuable tools for the teacher, but it is the curriculum that defines the objectives of teaching and the teacher who uses his or her expertise in planning and teaching the lessons (cf. Cunningsworth 1984, 1). Teachers could also pay more attention to opportunities for learning pronunciation outside of the classroom, and try to build bridges between learners' leisure and classroom activities. After all, many of the learners interviewed for the present study indicated that they had learnt English pronunciation outside school.

\footnotetext{
Acknowledgements

The author is grateful to the interviewees for sharing their views and experiences, and would also like to thank two additional experts for their contribution to the researcher triangulation. In addition, a warm thank you to Professor Hannele Dufva for her most helpful comments on the manuscript.
} 


\section{References}

Breitkreutz, J.A., T.M. Derwing \& M.J. Rossiter 2001. Pronunciation teaching practices in Canada. TESL Canada Journal 19 (1), 51-61.

Burgess, J. \& S. Spencer 2000. Phonology and pronunciation in integrated language teaching and teacher education. System 28 (2), 191-215.

Celce-Murcia, M., D.M. Brinton, J.M. Goodwin \& B. Griner 2010. Teaching Pronunciation. A Course Book and Reference Guide. Second edition. Cambridge: Cambridge University Press.

Cenoz, J.M. \& L. Garcia Lecumberri 1999. The Acquisition of English Pronunciation: Learners' Views. The International Journal of Applied Linguistics 9 (1), 3-17.

Cunningham, U. 2009. Models and Targets for Pronunciation of English in Vietnam and Sweden. Research in Language 7 (1), 113-128.

Cunningsworth, A. 1984. Evaluating and selecting EFL teaching materials. London: Heineman Educational Books.

Dalton-Puffer, C., G. Kaltenboeck \& U. Smit 1997. Learner Attitudes and L2 Pronunciation in Austria. World Englishes 16, 115-127.

Denzin, N.K. 1978. The research act: A theoretical introduction to sociological methods. Second edition. New York: McGraw-Hill.

Derwing, T.M. 2003. What do ESL students say about their accents? Canadian Modern Language Review 59, 547-567.

Finnish National Board of Education. 2004. National Core Curriculum for Basic Education. Helsinki: Author. Available at http://www.oph.fi/english/sources_of_information/core_curricula_and_qualification_ requirements/basic_education. [Retrieved 4 Feb 2013]

Fontana, A. \& A.H. Prokos 2007. The Interview: From Formal to Postmodern. Walnut Creek, CA: Left Coast Press.

Foote, J.A., A.K. Holtby \& T.M. Derwing 2011. Survey of the Teaching of Pronunciation in Adult ESL Programs in Canada, 2010. TESL Canada 29 (1), 1-22.

Fraser, H. 2000. Coordinating Improvements in Pronunciation Teaching for Adult Learners of English as a Second Language. Canberra: DETYA.

Gilbert, J.B. 2010. Pronunciation as orphan: What can be done? As We Speak, Newsletter of SPLIS, 2010.

Henderson, A., D. Frost, E. Tergujeff, A. Kautzsch, D. Murphy, A. Kirkova-Naskova, E. Waniek-Klimczak, D. Levey, U. Cunningham \& L. Curnick 2012. The English Pronunciation Teaching in Europe Survey: Selected results. Research in Language $10.1,5-27$.

Iivonen, A. 2005. Fonetiikan merkitys kielenomaksumisessa ja -opetuksessa. In A. Iivonen, R. Aulanko \& M. Vainio (eds.), Monikäyttöinen fonetiikka. Mimeographed series of the Department of Phonetics 21, University of Helsinki. 3 edition.

Janicka, K., M. Kul \& J. Weckwerth 2005. Polish Students' Attitudes to Native English Accents as Models for EFL Pronunciation. In K. Dziubalska-Kołaczyk \& J. Przedlacka (eds.), English Pronunciation Models: A Changing Scene. Bern: Peter Lang. 251-292.

Jenkins, J. 2000. Phonology of English as an international language. Oxford: Oxford University Press. 
Jones, K.W. 2001. "I've Called 'em Tom-ah-toes All My Life and I'm Not Going to Change!": Maintaining Linguistic Control over English Identity in the U.S. Social Forces 79 (3), 1061-1094.

Kachru, B.B. 1985. Standards, codification and sociolinguistic realism: The English language in the outer circle. In R. Quirk and H. Widdowson (eds.), English in the world: Teaching and learning the language and literatures. Cambridge: Cambridge University Press. 11-36.

Kumpulainen, T. (ed.) 2010. Koulutuksen määrälliset indikaattorit 2010. Helsinki: Finnish National Board of Education. Available at http://www.oph.fi/download/130716_Koulutuksen_maaralliset_indikaattorit_2010.p df._[Retrieved 4 Feb 2013]

Kvale, S. 2007. Doing interviews. London: Sage.

Leppänen, S., A. Pitkänen-Huhta, T. Nikula, S. Kytölä, T. Törmäkangas, K. Nissinen, L. Kääntä, T. Räisänen, M. Laitinen, P. Pahta, H. Koskela, S. Lähdesmäki \& H. Jousmäki 2011. National Survey on the English Language in Finland: Uses, meanings and attitudes. Studies in Variation, Contacts and Change in English, Vol. 5. Available at http://www.helsinki.fi/varieng/journal/volumes/05. [Retrieved $4 \mathrm{Feb}$ 2013]

Lintunen, P. 2004. Pronunciation and Phonemic Transcription: A study of advanced Finnish learners of English. Turku: University of Turku.

Luukka, M-R., S. Pöyhönen, A. Huhta, P. Taalas, M. Tarnanen \& A. Keränen 2008. Maailma mииttuu - mitä tekee koulu? Äidinkielen ja vieraiden kielten tekstikäytänteet koulussa ja vapaa-ajalla. University of Jyväskylä: Centre for Applied Language Studies.

Macdonald, S. 2002. Pronunciation - views and practices of reluctant teachers. Prospect 17 (3), 3-18.

Morley, J. 1991. The Pronunciation Component in Teaching English to Speakers of Other Languages. TESOL Quarterly 25 (3), 481-520.

Pihko, M-K. 1997. His English Sounded Strange. The Intelligibility of Native and NonNative English Pronunciation to Finnish Learners of English. University of Jyväskylä: Centre for Applied Language Studies.

Purcell, E.T. \& R. W. Suter 1980. Predictors of pronunciation accuracy: A reexamination. Language Learning 30 (2), 271-287.

Saito, K. 2012. Effects of Instruction on L2 Pronunciation Development: A Synthesis of 15 Quasi-Experimental Intervention Studies. TESOL Quarterly 46 (4), 842-854.

Suomi, K., J. Toivanen \& R. Ylitalo 2008. Finnish sound structure: Phonetics, phonology, phonotactics and prosody. Oulu: University of Oulu.

Suter, R.W. 1976. Predictors of pronunciation accuracy in second language learning. Language Learning 26 (2), 233-253.

Tergujeff, E. 2010. Pronunciation teaching materials in Finnish EFL textbooks. In A. Henderson (ed.), English Pronunciation: Issues and Practices (EPIP): Proceedings of the First International Conference. June 3-5 2009, Université de Savoie, Chambéry, France. Université de Savoie: Laboratoire LLS. 189-205.

Tergujeff, E. 2012a. English pronunciation teaching: Four case studies from Finland. Journal of Language Teaching and Research 3 (4), 599-607. 
Tergujeff, E. 2012b. The English Pronunciation Teaching in Europe Survey: Finland. Apples - Journal of Applied Language Studies 6 (1), 29-45.

Waniek-Klimczak, E. 1997. Context for Teaching English Phonetics and Phonology at Polish Universities and Colleges: A Survey. In Waniek-Klimczak, E. (ed.), Teaching English Phonetics and Phonology II. Accents '97. Łódź: Wydawnictwo Uniwersytetu Łódzkiego. 5-17.

Waniek-Klimczak, E. \& K. Klimczak 2005. Target in Speech Development: Learners' Views. In K. Dziubalska-Kołaczyk \& J. Przedlacka (eds.), English Pronunciation Models: A Changing Scene. Bern: Peter Lang. 229-249.

Wells, J.C. 1996. Why phonetic transcription is important. Malsori 31-32, 239-242. 